\title{
Biochemical and hormonal parameters of goats kept in a controlled environment consuming water with different levels of salinity
}

\author{
[Parâmetros bioquímicos e hormonais de caprinos consumindo água com diferentes \\ níveis de salinidade mantidos em ambiente controlado] \\ E.A. Cardoso $^{1}$, D.A. Furtado ${ }^{2}$, N.L. Ribeiro ${ }^{3 *}$, A.N. Medeiros ${ }^{4}$, E.P. Saraiva ${ }^{4}$ \\ J.W.B. Nascimento ${ }^{2}$, F.A. Sousa $a^{4}$, P.H.B. Pereira ${ }^{4}$ \\ ${ }^{1}$ Aluno de pós-graduação - Universidade Federal de Campina Grande - Campina Grande, PB \\ ${ }^{2}$ Universidade Federal de Campina Grande - Campina Grande, PB \\ 3Pesquisadora do Instituto Federal do Semiárido - Campina Grande, PB \\ ${ }^{4}$ Universidade Federal da Paraíba - Areia, PB
}

\begin{abstract}
The objective of this work was to evaluate the biochemical and hormonal variables of Moxotó and Canindé goats submitted to two temperatures $-26.0 \pm 0.6$ (thermoneutral) and $32.0 \pm 1.2^{\circ} \mathrm{C}$ (above thermal comfort zone) - and consuming water with three levels of salinity (1.0, 6.0 and $\left.12.0 \mathrm{dSm}^{-1}\right)$. Thirty-six animals (18 of each breed) were used, with an average age of 5.0 \pm 0.6 months and an average weight of $20.0 \pm 2.3 \mathrm{~kg}$, housed in metabolic cages inside a climate chamber. The animals were distributed in a completely randomized design with a $2 \times 2 \times 3$ factorial scheme ( 2 breeds, 2 temperatures and 3 levels of salinity) and three replications. The glucose and urea had a significant effect $(\mathrm{P}>0.05)$ according to water salinity. Glucose, cholesterol, protein, albumin, globulin, aspartate aminotransferase and hormones (T4, $\mathrm{T} 3$ and cortisol) varied according to temperature $(\mathrm{P}<0.05)$. There was a significant effect of time on hormonal variables $(\mathrm{P}<0.05)$. Biochemical and hormonal variables changed according to temperature and day shift, so that metabolism was reduced in the animals under thermal stress and accelerated when animals were in the thermal comfort zone.
\end{abstract}

Keywords: confinement, environment, goats, hormones, saltwater

\section{RESUMO}

O objetivo do trabalho foi avaliar as variáveis bioquímicas e hormonais de caprinos das raças Moxotó e Canindé, submetidos a duas temperaturas $\left(26,0 \pm 0,6^{\circ} \mathrm{C}\right.$ e $\left.32,0 \pm 1,2^{\circ} \mathrm{C}\right)$, termoneutra e acima da zona de conforto térmico, respectivamente), consumindo água com três níveis de salinidade (1,0, 6,0 e 12,0dSm

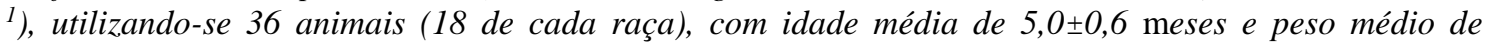
$20,0 \pm 2,3 \mathrm{~kg}$, alojados em gaiolas metabólicas no interior de uma câmara climática. Os animais foram distribuídos em um delineamento inteiramente ao acaso, com esquema fatorial de $2 \times 2 \times 3$ (2 raças, 2 temperaturas e 3 níveis de salinidade) e três repetições. A glicose e a ureia apresentaram efeito significativo $(P<0,05)$ em função da salinidade da água. Glicose, colesterol, proteína, albumina, globulina, AST e hormônios (T4, T3 e cortisol) variaram conforme as temperaturas $(P<0,05)$. Observouse efeito significativo do horário sobre as variáveis hormonais $(P<0,05)$. As variáveis bioquímicas e hormonais sofrem alterações em função da temperatura e do turno do dia, de modo que o metabolismo é reduzido em animais sob estresse térmico e acelerado quando os animais encontram-se na zona de conforto térmico.

Palavras-chave: ambiência, caprinocultura, salinidade, hormônios

Recebido em 15 de setembro de 2020

Aceito em 14 de outubro de 2020

*Autor para correspondência (corresponding author)

E-mail:neilalr@hotmail.com 


\section{INTRODUCTION}

Breeding small ruminants is a relevant activity in the Brazilian semiarid region, due to its productive and adaptive capacities and potential (Silva et al., 2016). In this scenario, locally adapted goat breeds, such as Moxotó and Canindé, stand out mainly in the dry period of the year, when temperatures are higher and the relative humidity is low. Goats have a thermoregulatory system to maintain a constant body temperature within certain limits, regardless of the ambient temperature (Silva et al., 2016). When the air temperature exceeds $28^{\circ} \mathrm{C}$, the physiological variables of the goats are changed, with these variables being higher (Araújo et al., 2017).

Water scarcity is a serious problem for arid and semi-arid regions. In the Brazilian semiarid region, the origin of water and the high rate of evaporation can decrease its availability and alter the composition and concentration of solutes, especially mineral salts (Melo et al., 2017); this change can leave saline water. While goats are tolerant of food consumption with high salt levels (Araújo et al., 2010; Yousfi et al., 2016; Castro et al., 2017; Mdletshe et al., 2017, Paiva et al., 2017), saline waters can negatively affect intake by goats, causing changes in the intracellular electrolyte balance, increase blood pressure, liver cirrhosis, intestinal and neurological gastric disorders; and changes the biochemical, hormonal and physiological variables of the animals (Boylaes, 2009).
Blood and hormonal parameters, in addition to being used to assess the animal's health status, are also useful for defining the stress level (Paes et al., 2000). Several factors can influence these variables, such as species, sex, race, age, physiological state and time of day (Al-Eissa et al., 2012; Ribeiro et al., 2018). Therefore, the present study aimed to evaluate the biochemical and hormonal variables of the Moxotó and Canindé goat breeds, submitted to two controlled temperatures in a climatic chamber, consuming water with three levels of salinity.

\section{MATERIAL AND METHODS}

The research was conducted in two climatic chambers at the Animal Bioclimatology Laboratory, Department of Zootechnics, Center for Agricultural Sciences, Federal University of Paraíba (UFPB), in Areia, Paraíba, Brazil. This study was approved by the Animal Ethics Committee of UFPB (protocol no. 6167/18). The animals were placed in two climatic chambers, each with an area of $19.71 \mathrm{~m}^{2}$, a ceiling height of $2.38 \mathrm{~m}$ made of laminated steel sheets (with a layer of polyurethane) and interior fluorescent lighting. The cooling system was a SPLIT model (Samsung Digital) air conditioner with a 30,000 BTU capacity, and the heating was through electric resistance air heaters. Adjacent to the climate chambers is a control room with a temperature and humidity control board (Figure $1)$.

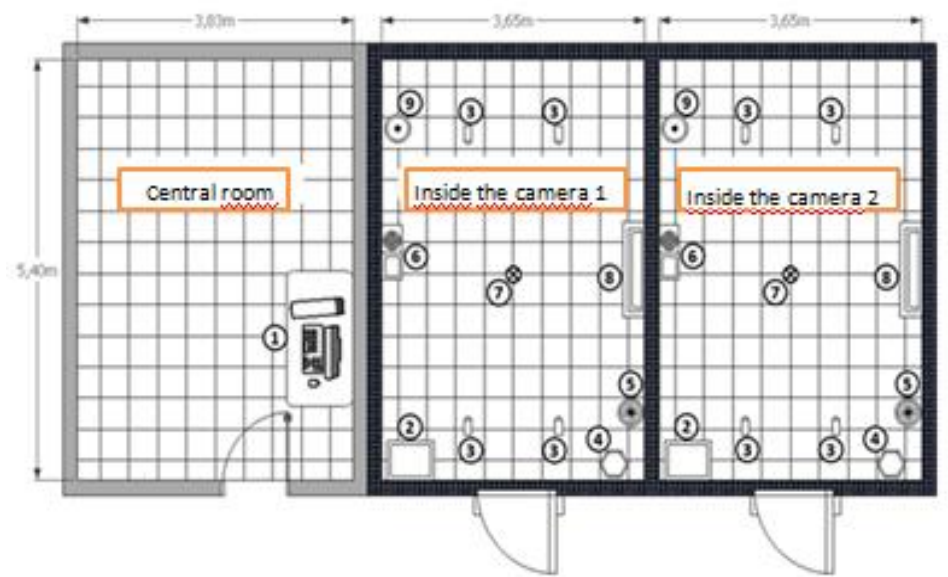

Figure 1. Climatic chamber used in the experiment. 1. Control panel / 2. Dehumidifier / 3. Camera / 4. Humidifier / 5. Exhaust (negative pressure) / 6. Heater / 7. Thermostat / 8. Air conditioning / 9. Exhaust (positive pressure) 
For humidification and dehumidification, a commercial humidifier and dehumidifier were used, specifically equipment coupled to the Fullgauge Controls $® \mathrm{mT}-530$ PLUS control system, configured by SITRAD software, responsible for recording and storing ambient temperature (TA) and relative humidity data of the air (UR). Data acquisition was performed through a thermistor (TA) and a humidistat (UR), both located in a permeable envelope and positioned at the height of the animals' mass centre $( \pm 1.50 \mathrm{~m})$.

Thirty-six non-castrated male animals - 18 Moxotó and 18 Canindé, which were initially weighed, identified and dewormed for endo- and ectoparasites - were used, at an average age of $5.0 \pm 0.6$ months, and a mean weight of $20.0 \pm 2.3 \mathrm{~kg}$. They were housed in metabolic cages $\left(1.20 \mathrm{~m} \times 0.50 \mathrm{~m}=0.60 \mathrm{~m}^{2}\right)$ inside the climatic chamber, provided with feeders and drinkers.

The animals were submitted to two temperatures: $\mathrm{T} 1=26 \pm 0.6^{\circ} \mathrm{C}$ (thermal comfort zone $[\mathrm{ZCT}]$ ) and $\mathrm{T} 2=32 \pm 1.2^{\circ} \mathrm{C}$ (above ZCT) (Lucena et al., 2013). The relative humidity and average wind speed were $67.6 \pm 5.0 \%$ and $2.0 \pm 0.4 \mathrm{~m} \mathrm{~s}^{-1}$, respectively. The experimental procedure was carried out in two stages, consisting of 36 animals (18 of each breed), at temperatures of 26 and $32^{\circ} \mathrm{C}$, and three levels of water salinity (1.0, 6.0 and $\left.12.0 \mathrm{dSm}^{-1}\right)$. The animals were kept at both temperatures for 23 hours, with the chamber being opened daily for 1 hour to clean the facilities and supply food and water.

In each treatment the animals were submitted to a lighting program, with the camera lights being turned off at 18:00h and turned on at 06:00h the next day, subjecting the animals to a period of 12hours of light and 12 hours of darkness. Before the experiment, the animals were kept in the climatic chamber for 20 days to adapt to the facilities and food. At the end of each period, blood was collected from the animals on day 25 (T1) and day 50 (T2) of the experiment. The ration was supplied ad libitum and was composed of Tifton hay (Cynodon dactylon (L.) Pers) ground and concentrated based on soy bran, corn bran, limestone and mineral core as $50 \%$ concentrate and $50 \%$ roughage. The feed was formulated to satisfy a weight gain of $250 \mathrm{~g}$ day $^{-1}$ (Nutrient..., 2007) per animal and was available twice daily, at 08:00h and 16:00h. Feed consumption was controlled according to the diet provided and leftovers, which was adjusted daily to allow $20 \%$ leftovers.

The supplied water came from an artesian well located in the Department of Animal Science, CCA, UFPB, Areia, which was subjected to chemical analysis to control salinity levels. The water was supplied ad libitum, the consumption being quantified according to the daily total supplied $(7.0 \mathrm{~L})$ minus the leftovers in the 24hour period. For both food and water, consumption was determined by weighing on the scale. Increasing salinity levels of the water were obtained by dissolving sodium chloride $(\mathrm{NaCl})$ in the water, the amount of which was determined by the electrical conductivity of water (ECa), according to the equation proposed by Richards (1954), in order to achieve the desired levels (1.6 and $\left.12 \mathrm{dSm}^{-1}\right)$. With the aid of a portable digital conductivity meter (model ITCD-1000, Instrutemp), the conductivity of the water to which $\mathrm{NaCl}$ would be added was measured. Given the result, $\mathrm{NaCl}$ was dissolved and mixed in water until the solution reached the desired electrical conductivity, according to analysis (Table 1)

Table 1. Mean values of the conductivity variables, sodium, chlorine, calcium, magnesium, potassium and $\mathrm{pH}$ of the waters offered to experimental goats

\begin{tabular}{lccc}
\hline \multicolumn{1}{c}{ Variables } & \multicolumn{2}{c}{ Total dissolved solids in the water $\left(\mathrm{mg} \mathrm{L}^{-1}\right)$} \\
\cline { 2 - 4 } & 1.0 & 6.0 & 12.0 \\
\hline $\mathrm{pH}$ & 6.20 & 6.40 & 6.60 \\
Conductivity $\left(\mu \mathrm{S} \mathrm{Cm}^{-1}\right)$ & 0.09 & 5.26 & 11.42 \\
Calcium $\left(\mathrm{mg} \mathrm{L}^{-1}\right)$ & 32.0 & 15.0 & 18.0 \\
Magnesium $\left(\mathrm{mg} \mathrm{L}^{-1}\right)$ & 35.0 & 30.0 & 30.0 \\
Sodium $\left(\mathrm{mg} \mathrm{L}^{-1}\right)$ & 0.63 & 62.7 & 137.4 \\
Potassium $\left(\mathrm{mg} \mathrm{L}^{-1}\right)$ & 7.0 & 7.0 & 7.0 \\
Chlorine $\left(\mathrm{mg} \mathrm{L}^{-1}\right)$ & 1.83 & 78.5 & 176.5 \\
\hline
\end{tabular}


Blood samples from each animal were collected at $5,8,11,14$ and 17 hours, through puncture in the jugular vein, after asepsis with iodized alcohol, with minimal trauma. The collections utilized $0.8 \times 25 \mathrm{~mm}$ needles and $5 \mathrm{ml}$ vacuum tubes containing the anticoagulant ethylene sodium diaminotetracetate (10\% EDTA). Blood samples were kept in isothermal boxes with ice until they arrived at the Animal Physiology and Molecular Biology laboratory (UFPB-CCA). In the laboratory, the samples were centrifuged in a digital centrifuge at $4^{\circ} \mathrm{C}$ at $1100 \mathrm{~g}$ for 15 minutes. The supernatant resulting from the centrifugation was separated into $1.5 \mathrm{ml}$ aliquots and stored at $20^{\circ} \mathrm{C}$ (Njidda et al., 2014) for biochemical measurements.

The data were analyzed using a biochemical analytical device with a multiple wavelength photometer (Thermo Scientificgenesys 10SVis, USA) for the following biochemicals: total protein (PRT), by the biuret colourimetric method; albumin (ALB), by the bromocresol colourimetric method; glucose (GLI), by the gOD-Trinder method; triglycerides (TRI), by the enzymatic Trinder method; cholesterol (COL), by the enzymatic Trinder method; urea (URE); creatinine (CRE), by the Jaffe kinetic method; gamma glutamyl transferase SL (GGT), by the Szasz-Tris kinetic method; and aspartate aminotransferase (AST), by the UV kinetic method.

Plasma concentrations of cortisol, trioxin (T4) and triiodothyronine (T3) were analyzed in duplicates using enzyme-linked immunosorbent assays developed for quantitative assessment of hormones. Plasma T3, T4 and cortisol concentrations were analyzed, in duplicates, using a solid phase radioimmunoassay method. For this purpose, sets of commercial reagents were used, developed for the quantitative evaluation of hormones, without any type of chemical extraction and purification process, using iodine-125 as a tracer radioactive element. The utilized COAT-A-COUNT procedures were those specified by the manufacturer. All biochemical and hormonal procedures were performed using laboratory kits for commercial use (Labtest). The averages of the results were evaluated using analysis of variance (ANOVA); to compare the averages, the general linear model procedure was used with the Tukey test at the level of 5\% probability, as well as regression analysis by PROC REG with the aid of SAS 9.1 software (2001).

\section{RESULTS AND DISCUSSION}

There were no significant differences $(\mathrm{P}>0.05)$ between the means of the biochemical and hormonal variables in the different breeds, with the exception of the glutamyl transferase range, which was higher in the Moxotó breed (Table 2). These values are within the standards established for caprine species and similar to those cited by Kaneko et al. (2009) and Ribeiro et al. (2018). This similarity may have occurred due to the management and origin of breeds native to the Brazilian semiarid region; they have undergone similar processes of natural selection and are adapted to the edaphoclimatic conditions of the region, with a good ability to withstand high temperatures (Al-Eissa et al., 2012; Ribeiro et al., 2018).

Water scarcity and quality are serious problems in arid and semi-arid regions; these problems are more severe in summer, when good quality drinking water is reduced. In this context, the use of locally adapted breeds is important for the development of animal production in regions with challenging environments. The species in these regions have developed the adaptive capacity to survive in adverse conditions such as water stress (Njidda et al., 2014). After the first adaptive changes that occur in the animal, in response to the increase in respiratory rate, heart rate and surface temperature, the hypothalamicpituitary-adrenal (HHA) system is activated, thus increasing the level of cortisol and decreasing the level of cholesterol. These changes provide greater availability of energy substrates for cells, a phenomenon that reduces cellular glucose consumption, which is less important in stress conditions (Piccione et al., 2012).

There was no significant effect $(\mathrm{P}<0.05)$ of the different temperatures on the biochemical variables of glucose, cholesterol, protein, albumin, globulin, AST and hormones (T4, T3 and cortisol) (Table 3). Glucose showed a lower concentration at the highest temperature, which is related to the fact that animals spend more energy to maintain homeothermy, mobilizing energy sources, mainly to eliminate body heat. The glucose, cholesterol, protein and globulin 
values are in accordance with those observed by Kaneko et al. (2009) for the evaluated goat species. Cholesterol values were lower at $32^{\circ} \mathrm{C}$, as a consequence of the decrease in glucose concentration caused by thermal stress; these findings are consistent with Ribeiro et al. (2016).
In a stressful situation, cholesterol levels decrease, and cortisol synthesis increases in response to heat stress. Cortisol limits the use of glucose and, under these conditions, the animal mobilizes other energy reserves such as triglycerides and proteins (Sejian et al., 2010).

Table 2. Mean and standard deviation of biochemical and hormonal variables of goats of the Moxotó and Canindé breeds, confined in climatic chambers at temperatures of 26 and $32^{\circ} \mathrm{C}$

\begin{tabular}{|c|c|c|c|c|}
\hline \multirow[t]{2}{*}{ Variables } & \multicolumn{2}{|c|}{ Breed } & \multicolumn{2}{|c|}{ Temperature $\left({ }^{\circ} \mathrm{C}\right)$} \\
\hline & Canindé & Moxotó & 26 & 32 \\
\hline \multicolumn{5}{|c|}{ Biochemical } \\
\hline Glucose $\left(\mathrm{mg} \mathrm{dL}^{-1}\right)$ & $76.40 \pm 20.79$ & $71.31 \pm 20.91$ & $85.46 \pm 15.37 a$ & $63.02 \pm 19.57 b$ \\
\hline Urea $\left(\mathrm{mg} \mathrm{dL}^{-1}\right)$ & $78.29 \pm 16.09$ & $77.78 \pm 17.45$ & $78.31 \pm 18.80$ & $77.76 \pm 14.69$ \\
\hline Triglycerides $\left(\mathrm{mg} \mathrm{dL}^{-1}\right)$ & $140.37 \pm 20.74$ & $141.23 \pm 20.97$ & $144.38 \pm 21.70$ & $137.48 \pm 19.46$ \\
\hline Cholesterol (mg dL $\left.\mathrm{m}^{-1}\right)$ & $91.33 \pm 18.54$ & $82.42 \pm 31.31$ & $93.02 \pm 22.44 \mathrm{a}$ & $80.15 \pm 28.21 b$ \\
\hline Total Protein $\left(\mathrm{mg} \mathrm{dL}^{-1}\right)$ & $6.00 \pm 1.48$ & $5.89 \pm 0.87$ & $6.58 \pm 0.63 a$ & $5.36 \pm 1.30 \mathrm{~b}$ \\
\hline Albumin $\left(\mathrm{mg} \mathrm{dL}^{-1}\right)$ & $2.67 \pm 0.67$ & $2.37 \pm 0.70$ & $2.77 \pm 0.36 \mathrm{a}$ & $2.28 \pm 0.84 b$ \\
\hline Globulin $\left(\mathrm{mg} \mathrm{dL}^{-1}\right)$ & $3.34 \pm 1.19$ & $3.53 \pm 0.99$ & $3.81 \pm 0.72 \mathrm{a}$ & $3.08 \pm 1.25 b$ \\
\hline Albumin/Globulin & $0.98 \pm 0.73$ & $0.77 \pm 0.40$ & $0.77 \pm 0.25$ & $0.97 \pm 0.78$ \\
\hline $\operatorname{AST}\left(\mathrm{U} \mathrm{l}^{-1}\right)$ & $77.41 \pm 14.44$ & $75.22 \pm 14.46$ & $71.12 \pm 12.06 b$ & $81.11 \pm 14.85 \mathrm{a}$ \\
\hline GGT $\left(\mathrm{U} \mathrm{l}^{-1}\right)$ & $38.35 \pm 6.88 b$ & $42.93 \pm 8.36 \mathrm{a}$ & $40.33 \pm 7.91$ & $40.98 \pm 8.09$ \\
\hline \multicolumn{5}{|c|}{ Hormonal } \\
\hline Cortisol $\left(\right.$ ngmL $\left.^{-1}\right)$ & $5.96 \pm 0.78$ & $6.31 \pm 1.10$ & $5.86 \pm 1.00 \mathrm{~b}$ & $6.44 \pm 0.84 a$ \\
\hline $\mathrm{T} 3\left(\mu \mathrm{g} \mathrm{dL^{-1 }}\right)$ & $1.42 \pm 0.34$ & $1.36 \pm 0.37$ & $1.56 \pm 0.36 \mathrm{a}$ & $1.23 \pm 0.27 b$ \\
\hline $\mathrm{T} 4\left(\mathrm{ngmL}^{-1}\right)$ & $2.10 \pm 0.60$ & $1.99 \pm 0.62$ & $2.11 \pm 0.56$ & $1.97 \pm 0.66$ \\
\hline
\end{tabular}

Averages in rows followed by different letters are statistically different by the Tukey test $(\mathrm{P}<0.05)$; AST $=$ aspartate aminotransferase; gGT =gamma SLgT; T4 = total thyroxine; T3 = total triiodothyronine

Total protein, albumin and globulin showed lower concentrations at $32^{\circ} \mathrm{C}$; these changes favor adaptation to stress, and differences in the value of globulin are due to adaptive factors of physiological and genetic order. Abdalla et al. (2009), Al-Eissa et al. (2012) and Ribeiro et al. (2016) also reported a lower globulin level at high temperatures. In the present study, the AST concentration was higher at the higher temperature $\left(32^{\circ} \mathrm{C}\right)$.

Hormone levels showed the action of air temperature on the animals' endocrine and thermoregulatory physiology. There were decreased plasma T3 and T4 levels in the animals when the temperature rose from 26 to $32^{\circ} \mathrm{C}$. These results are similar to other studies that have demonstrated the existence of a high and inversely proportional correlation between the concentrations of thyroid hormones and the ambient temperature in goats, a phenomenon that is an adaptive mechanism to reduce heat production (Ribeiro et al., 2016, 2018). It is common for $\mathrm{T} 4$ and $\mathrm{T} 3$ concentrations to decrease as the air temperature increases (Helal et al., 2010; Costa et al., 2015); this decrease is an adaptive mechanism to reduce heat stress.

The highest average cortisol values were recorded at $32^{\circ} \mathrm{C}$, as high temperatures hinder the process of thermolysis in animals. The observed cortisol level is within the range reported in studies in different goat breeds, which vary from 3 to $15 \mathrm{ngml}^{-1}$ (Costa et al., 2015; Ribeiro et al., 2015). They were close to the average values described by Ribeiro et al. (2018) but below the average value reported by Ribeiro et al. (2016). Animal metabolism is reduced during high temperature stress and accelerated during low temperature stress and these changes are controlled by thyroid hormones and cortisol (Helal et al., 2010), which facilitate the physiological changes involved in adaptation.

Homeostatic mechanisms control the level of minerals in body fluids; therefore, metabolite concentrations tend to stabilize after a period of saline water intake (Thomas et al., 2006). Increased serum metabolite concentrations in sheep that received the highest salt water can be 
detrimental to homeostasis in the long run (Elgharbi et al., 2015). There were significant variations $(\mathrm{P}<0.05)$ in the levels of urea and triglycerides as a function of water salinity levels. Urea levels were higher at the level of 6.0 $\mathrm{dSm}^{-1}$ and lower at $12.0 \mathrm{dSm}^{-1}$, while triglyceride levels were higher at $12.0 \mathrm{dSm}^{-1}$ and lower 6.0 $\mathrm{dSm}^{-1}$ (Table 3). The variations observed in urea and triglycerides were normal because they remained within the recommended average for caprine species; this outcome reflects the adaptability of the animals to saline water.
Hormonal levels were not affected $(\mathrm{P}>0.05)$ by water salinity levels (Table 3 ), even in animals that consumed water with high sodium and chlorine levels. The excess $\mathrm{NaCl}$ absorbed by the animals may be less assimilated in the digestive tract and, consequently, not as well absorbed by the cells of the body. Rather, it would be eliminated via sweat, urine and feces (Gonzalez, 2000). The means of $\mathrm{T} 4$ and cortisol varied at different times of the day $(\mathrm{P}<0.05)($ Table 4$)$.

Table 3. Mean and standard deviation of the biochemical and hormonal variables of the blood of goats of the Moxotó and Canindé breed as a function of the salinity levels of the water offered during the experiment

\begin{tabular}{|c|c|c|c|}
\hline \multirow{2}{*}{ Variables } & \multicolumn{3}{|c|}{ Salinity $\left(\mathrm{dSm}^{-1}\right)$} \\
\hline & 1.0 & 6.0 & 12.0 \\
\hline \multicolumn{4}{|c|}{ Biochemical } \\
\hline Glucose $\left(\mathrm{mg} \mathrm{dL}^{-1}\right)$ & $77.66 \pm 17.61$ & $71.40 \pm 2.65$ & $71.47 \pm 22.79$ \\
\hline Urea $\left(\mathrm{mg} \mathrm{dL}^{-1}\right)$ & $80.17 \pm 15.13 b$ & $84.87 \pm 21.14 \mathrm{a}$ & $72.10 \pm 13.57 \mathrm{c}$ \\
\hline Triglycerides $\left(\mathrm{mg} \mathrm{dL}^{-1}\right)$ & $139.65 \pm 18.53 \mathrm{ab}$ & $131.36 \pm 14.47 b$ & $147.23 \pm 23.80 \mathrm{a}$ \\
\hline Cholesterol $\left(\mathrm{mg} \mathrm{dL}^{-1}\right)$ & $85.88 \pm 24.46$ & $91.05 \pm 31.23$ & $85.36 \pm 24.95$ \\
\hline Total Protein $\left(\mathrm{mg} \mathrm{dL}^{-1}\right)$ & $6.01 \pm 1.09$ & $5.95 \pm 1.21$ & $5.88 \pm 1.33$ \\
\hline Albumin $\left(\mathrm{mg} \mathrm{dL}^{-1}\right)$ & $2.65 \pm 0.66$ & $2.68 \pm 0.71$ & $2.29 \pm 0.69$ \\
\hline Globulin ( $\left.\mathrm{mg} \mathrm{dL}^{-1}\right)$ & $3.36 \pm 0.99$ & $3.27 \pm 0.94$ & $3.60 \pm 1.26$ \\
\hline Albumin/Globulin & $0.90 \pm 0.40$ & $0.90 \pm 0.38$ & $0.84 \pm 0.82$ \\
\hline $\operatorname{AST}\left(\mathrm{U} \mathrm{l}^{-1}\right)$ & 76.3413 .42 & $75.27 \pm 15.71$ & $76.85 \pm 14.98$ \\
\hline GGT $\left(\mathrm{U} \mathrm{l}^{-1}\right)$ & $40.94 \pm 8.35$ & $40.89 \pm 6.72$ & $40.28 \pm 8.43$ \\
\hline \multicolumn{4}{|c|}{ Hormonal } \\
\hline Cortisol $\left(\right.$ ngmL $\left.^{-1}\right)$ & $6.29 \pm 0.97$ & $5.97 \pm 0.96$ & $6.09 \pm 0.98$ \\
\hline $\mathrm{T} 3\left(\mu \mathrm{g} \mathrm{dL}^{-1}\right)$ & $1.43 \pm 0.34$ & $1.33 \pm 0.35$ & $1.38 \pm 0.37$ \\
\hline $\mathrm{T} 4\left(\mathrm{ngmL}^{-1}\right)$ & $2.11 \pm 0.61$ & $2.03 \pm 0.71$ & $1.99 \pm 0.56$ \\
\hline
\end{tabular}

Averages in rows followed by different letters are statistically different by the Tukey test $(\mathrm{P}<0.05)$; AST $=$ aspartate aminotransferase; gGT =gamma SLgT; T4 = total thyroxine; T3 = total triiodothyronine

Table 4. Mean and regression parameters of the hormonal variables of the blood of goats of the Moxotó and Canindé breed collected from 5 am to $5 \mathrm{pm}$

\begin{tabular}{lccc}
\multicolumn{1}{c}{ Hours } & $\mathrm{T} 4\left(\mathrm{ngmL}^{-1}\right)^{1}$ & $\mathrm{~T} 3\left(\mathrm{ngmL}^{-1}\right)$ & Cortisol $\left(\mathrm{ngmL}^{-1}\right)^{2}$ \\
\hline $05: 00$ & $3.13 \mathrm{a}$ & 1.45 & $5.46 \mathrm{cb}$ \\
$08: 00$ & $2.43 \mathrm{~b}$ & 1.52 & $6.48 \mathrm{ab}$ \\
$11: 00$ & $1.62 \mathrm{c}$ & 1.29 & $6.76 \mathrm{ab}$ \\
$14: 00$ & $1.40 \mathrm{c}$ & 1.39 & $7.07 \mathrm{a}$ \\
17:00 & $2.22 \mathrm{~b}$ & 1.21 & $5.10 \mathrm{c}$ \\
\hline SEM & 0.35 & 0.37 & 0.84 \\
\hline \multicolumn{5}{c}{} \\
\hline Linear & 0.0089 & $P$-value & 0.2297 \\
Quadratic & $<.0001$ & 0.1322 & $<.0001$ \\
\hline
\end{tabular}

Averages in rows followed by different letters are statistically different by the Tukey test $(\mathrm{P}<0.05) ; \mathrm{SEM}=$ standard error means; $\mathrm{T} 4=$ total thyroxine; $\mathrm{T} 3=$ total triiodothyronine; ${ }^{\mathrm{Y}} \mathrm{Y}=6.17+0.73 \mathrm{x}-0.03 \mathrm{x}^{2}\left(\mathrm{R}^{2}=0.93\right) ;{ }^{2} \mathrm{Y}=1.36+1.03 \mathrm{x}-$ $0.04 \mathrm{x}^{2}\left(\mathrm{R}^{2}=0.88\right)$

T4 showed a decreasing concentration until 14:00h, and at 17:00h it increased again, but T3 remained stable throughout the period $(\mathrm{P}>0.05)$. $\mathrm{T} 4$ and cortisol showed a positive quadratic 
regressive effect $(\mathrm{P}<0.0001)$, with higher values throughout the day and decreasing at 17 hours. This variation occurs because these hormones are circadian and the thyroid and adrenal glands play fundamental roles in the adaptation mechanism. Therefore, animals in these conditions respond quickly to environmental changes, with the necessary physiological adjustments (Sejian, 2013; Ribeiro et al., 2015). The T4 and T3 concentrations may decrease as the air temperature increases (Helal et al., 2010; Costa et al., 2015), which is due to the adaptive processes triggered by the body to reduce heat stress.

\section{CONCLUSIONS}

The gamma glutamyl transferase enzyme varied depending on the breed but remained within the limit established for the goat species. Glucose, protein, albumin, globulin and T3 showed higher values at $26^{\circ} \mathrm{C}$, while the AST and cortisol showed higher concentrations at $32^{\circ} \mathrm{C}$. The salinity of the water caused changes in the levels of urea and blood triglyceride. The time of day should be considered in studies of hormonal levels of animals, such as cortisol, which had the highest concentrations at 14:00h, the same time when the T3 concentration was the lowest.

\section{REFERENCE}

ABDALLA, M.; ABDELATIF, M.; IBRAHIM, Y. et al. Seasonal variation in erythrocytic and leukocytic indices and serum proteins of female Nubiangoats. Middle-East J. Sci. Res., v.4, p.168-174, 2009.

AL-EISSA, M.S.; SAAD, A.; AL-FARRAJ, S.A. et al. Seasonal variation effects on the composition of blood in Nubian ibex (Capra nubiana) in Saudi Arabia. Afr. J. Biotechnol. v.11, p.1283-1286, 2012.

ARAÚJO, G.G.L.; VOLTOLINI, T.V.; CHIZZOTTI, M.L. et al. Water and small ruminant production. Rev. Bras. Zootec., v.36, p.326-336, 2010.

ARAÚJO, T.G.P.; FURTADO, D.A.; NASCIMENTO, J.W.B. et al. Thermoregulatory responses and adaptability of Anglonubianagoatsmaintained in thermoneutral temperature and underheat stress. J. Anim. Behav. Biometeorol., v.5, p.106-111, 2017.
BOYLES, S. Livestock and water. The Ohio State University Extension, 2009. 18p. Available in: http:// www.ag.ohiostate.edu/ beef/library/water.html. Accessed in: 05 Dec. 2017.

CASTRO, D.P.V.; YAMAMOTO, S.M.; ARAÚJO, G.G.L. et al. Influence of drinking water salinity on carcass characteristics andmeat quality of Santa Inês lambs. Trop. Anim. Health Prod., v.49, p.1095-1100, 2017.

COSTA, R.G.; RIBEIRO, J.M.; RIBEIRO, N.L. et al. Efeito da estação sobre as respostashormonais de caprinos crioulos do semiárido do Brasil. Actas Iberoam. Conserv. Anim., v.6, p.424-431, 2015.

ELGHARBI, W.M.; ABIDI, S.; SALEM, H.B. Effects of water salinity onmilk production and several blood constituents of Barbarine sheep in a semiarid climate. Int. Res. J. Earth Sci., v.3, p.1-4, 2015.

GONZÁLEZ, F.H.D. Uso de perfilmetabólico para determinar o status nutricional emgado de corte. In:gONZÁLEZ, F.H.D.; BARCELLOS, J.O; OSPINA,h.; RIBEIRO, L.A.O. (Eds.). Perfil metabólico em ruminantes: seu uso em nutrição e doenças nutricionais. Porto Alegre, Universidade Federal do Rio Grande do Sul, 2000.

HELAL, A.; HASHEM, A.L.S.; ABDELFATTAH, M.S. et al. Effect of heat stress on coat characteristics and physiological responses of Balady and Damascus goats in Sinai, Egypt. Am. Eurasian J. Agricul. Environ. Sci., v.7, p.6069, 2010.

KANEKO, J.J.; HARVEY, J.W.; BRUSS, M.L. Clinical biochemistry of domestic animals. London: Academic Press, 2009. 928p.

LUCENA, L.F.A.; FURTADO, D.A.; NASCIMENTO, J.W.B. et al. Physiological responses of native goats maintained in a thermoneutral temperature and thermal stress. Rev. Bras. Eng. Agr. Amb., v.17, p.672-679, 2013.

MDLETSHE, Z.M.; CHIMONYO, M.; MARUFU, M.C. et al. Effects of saline water consumption on physiological responses in Ngunigoats. Small Ruminant Res., v.153, p.209211, 2017. 
MELO, D.F.; FURTADO, D.A.; DANTAS NETO, J. et al. Physiochemical quality of waters of different sources used for animal consumption in the semiarid Brazilian. Rev. Espacios, v.38, p.28-35, 2017.

NIJDDA, A.A.; SHUAI'BU, A.A.; ISIDAHOMEN, C.E. Hematological and serum biochemical indices of sheep in semi-arid environment of northern Nigeria. Global J. Sci. Front. Res., v.14, p.49-56, 2014.

NUTRIENT requirements of small ruminants: sheep, goats, cervids, and new world camelids. Washington, D.C.: National Academy Press, 2007. 362p.

PAES, P.R.; BARIONI, G.; FONTEQUE, J.R. et al. Comparação dos valores hematológicos entre caprinos fêmeas da raça Parda Alpina de diferentes faixas etárias. Vet. Notícia, v.6, p.4349, 2000.

PAIVA, G.N.; ARAÚJO, G.G.L.; HENRIQUES, L.T. et al. Water with different salinity levels for lactating goats. Semin. Cienc. Agrar., v.38, p.2065-2074, 2017.

PICCIONE, G.; MESSINA, V.; VAZZANA, I. et al. Seasonal variations of some serum electrolyte concentrations in sheep and goats. Comp. Clin. Pathol., v.21, p.911-915, 2012.

RIBEIRO, N.L.; COSTA, R.G.; PIMENTA FILHO, E.C. et al. Adaptive profile of garfagnina goat breed assessed through physiological, haematological, biochemical and hormonal parameters. Small Ruminant Res., v.144, p.236-241, 2016.

RIBEIRO, N.L.; COSTA, R.G.; PIMENTA FILHO, E.C. et al. Effects of the dry and the rainy season on endocrine and physiologic profiles goats in the Brazilian semi-arid region. Ital. J. Anim. Sci., v.17, p.454-461, 2018.
RIBEIRO, N.L.; PIMENTA FILHO, E.C.; ARANDAS, J.K.G. et al. Multivariate characterization of the adaptive profile in Brazilian and Italian goat population. Small Ruminant Res., v.123, p.232-237, 2015.

RICHARDS, L.A. Diagnosis and improvement of saline and alkali soils. Washington DC: US Department of Agriculture, USDA Agricultural Handbook, 1954, 160p

SAS system for Windows. Version 9.1. Cary: SAS Institute Inc., 2001.

SEJIAN V. Climate change: impact on production and reproduction, adaptation mechanisms and mitigation strategies in small ruminants: a review. Indian J. Small Ruminant, v.19, p.1-21, 2013.

SEJIAN, V.; MAURYA, V.P.; NAQVI, S.M.K. Adaptability andgrowth ofmalpura ewes subjected to thermal and nutritional stress. Trop. Anim. Health Prod., v.42, p.1763-1770, 2010.

SILVA, R.M.; SOUZA, B.B.; GUIMARÃES, L.J. et al. Estresse térmico e sua influência na fisiologia hormonal de pequenos ruminantes. $J$. Anim. Behav. Biometeorol., v.4, p.50-54, 2016.

THOMAS D.T.; RINTOUL A.J.; MASTERS D.G. Sheep select combinations of high and low sodium chloride, energy and crude protein feed that improve their diet, Appl. Anim. Behav. Sci., v.105, p.140-153, 2006.

YOUSFI, I.; BEN SALEM, H.; AOUADI, D.; ABIDI, S. Effect of sodium chloride, sodium sulfate or sodium nitrite in drinking water on intake, digestion, growth rate, carcass traits and meat quality of Barbarine lamb. Small Ruminant Res., v.143, p.43-52, 2016. 